\title{
HUBUNGAN AKTIVITAS PENDUKUNG TERHADAP KUALITAS VISUAL KORIDOR JALAN GAJAH MADA PONTIANAK
}

\author{
Riesa Rizki Amalia', Bontor Jumaylinda Br. Gultom², M. Nurhamsyah ${ }^{3}$ \\ ${ }^{1}$ Mahasiswa, Jurusan Arsitektur, Fakultas Teknik, Universitas Tanjungpura \\ riesaamalia99@gmail.com \\ ${ }^{2}$ Jurusan Arsitektur, Fakultas Teknik, Universitas Tanjungpura \\ ${ }^{3}$ Jurusan Arsitektur, Fakultas Teknik, Universitas Tanjungpura
}

Naskah diajukan pada: 18 Juni 2021

Naskah revisi akhir diterima pada: 24 Juni 2021

\begin{abstract}
Abstrak
Penelitian ini didasari oleh adanya kekhawatiran mengenai keberadaan aktivitas pendukung akan memberikan dampak pada kualitas visual suatu koridor jalan komersial. Aktivitas yang muncul pada koridor komersial adalah aktivitas perdagangan dan jasa serta aktivitas pendukung. Aktivitas pendukung inilah yang akan berpengaruh pada perkembangan kota sehingga lebih hidup, menerus, serta damai. Pada sebuah koridor aktivitas-aktivitas ini dapat mendatangkan banyak pengunjung. Banyaknya pengunjung ini menandakan bahwa koridor tersebut memiliki daya tarik. Metode yang digunakan dalam penelitian ini berupa metode pemetaan perilaku dan space syntax yang dikombinasikan dengan kuesioner. Kemudian hasil data-data ini dikorelasikan sehingga dapat mengetahui hubungan aktivitas pendukung terhadap kualitas visual koridor. Hasil temuan penelitian ini berupa hubungan aktivitas pendukung terhadap kualitas visual koridor Jalan Gajah Mada Pontianak. Korelasi data antara placed centered mapping dan space syntax, antara placed centered mapping dan kuesioner, serta antara kuesioner dan space syntax, menunjukkan korelasi yang positif. Jumlah dan posisi dari aktivitas pendukung berupa keberadaan PKL dapat meningkatkan pergerakan pada suatu area. Pergerakan yang tinggi pada space syntax dapat menandakan bahwa kualitas visual pada suatu area memiliki nilai yang tinggi. Ruang yang mudah untuk dikenali akan menarik pengunjung untuk datang dan aktivitas pendukung berupa PKL dapat menjadi movement generator dan attractor.
\end{abstract}

Kata-kata Kunci: Aktivitas Pendukung, Kualitas Visual Koridor, Jalan Gajah Mada Pontianak

\begin{abstract}
This research is based on concerns about the existence of supporting activities will have an impact on the visual quality of a commercial road corridor. Activities that appear in commercial corridors are trade and service activities as well as activity support. This activity support will affect the development of the city so that it is more lively, continuous, and peaceful. In a corridor these activities can bring a lot of visitors. The large number of visitors indicates that the corridor has an attraction. The method used in this study is a method of mapping behavior and space syntax combined with questionnaires. Then the results of these data are correlated so as to know the relationship of supporting activities to the visual quality of corridors. The findings of this study are in the form of supporting activity relationship to the visual quality of the corridor of Jalan Gajah Mada Pontianak. The correlation of data between placed centered mapping and space syntax, between placed centered mapping and questionnaires, as well as between questionnaires and space syntax, showed a positive correlation. The number and position of supporting activities in the form of pkl can increase movement in an area. High movement in space syntax can indicate that the visual quality of an area has a high value. An easy-to-recognize space will attract visitors to come and supporting activities in the form of street vendors can be a movement generator and attractor.
\end{abstract}

Keywords: Activity Support, Visual Quality of Corridor, Gajah Mada Street Pontianak 


\section{Pendahuluan}

Sebuah perkotaan aktivitas akan muncul pada area publik seperti square dan jalan (Krier, 1979). Jalan merupakan satu diantara fasilitas umum yang digunakan masyarakat untuk tetap terhubung antar wilayah sehingga mempermudah masyarakat untuk beraktivitas. Jalan juga harus dapat membantu menciptakan komunitas, menyediakan fasilitas untuk berkomunikasi dan berinteraksi, memberikan kenyamanan, keamanan, dapat dikenang, serta representatif (Jacobs, 1993).

Koridor pada umumnya terbentuk dari jalan, sidewalk, fasad bangunan atau halaman bangunan (Bishop dalam Hasanah, 2014). Koridor merupakan ruang pergerakan (sirkulasi) memiliki dua pengaruh langsung untuk kualitas lingkungan, yaitu kelangsungan aktivitas komersial dan kualitas visual yang kuat terhadap struktur dan bentuk fungsi kota (Halim \& Alimuddin, 2016). Koridor jalan komersial merupakan ruang publik yang berbentuk linier dengan dominasi kegiatan berupa fungsi komersial (Setyowati, 2017). Ciri khasnya ditentukan oleh bangunan yang mencakupinya dan aktivitas yang ada pada koridor tersebut (Krier, 1979).

Dilansir dari eQuator.co.id, dahulunya koridor Jalan Gajah Mada Pontianak hanyalah daerah pinggiran kota. Seiring dengan berkembangnya waktu, koridor jalan ini telah tumbuh menjadi koridor jalan komersial yang memiliki beragam aktivitas perdagangan dan jasa. Bangunan-bangunan yang mendukung aktivitas ini berupa ruko, toko, warung, supermarket, pasar, hingga hotel.

Lokasi dari koridor ini berada dekat dengan pusat pemerintahan, Pelabuhan Dwikora, dan Sungai Kapuas yang menjadi jalur perdagangan di Kota Pontianak. Berdasarkan Jati et al. (2021) koridor jalan ini merupakan area disekitar CBD (Central Business District) dan pada Rencana Tata Ruang Wilayah Kota Pontianak Tahun 2013-2033 telah ditetapkan sebagai Pusat Pelayanan Kota (PPK) untuk area perdagangan dan jasa (Lihat Gambar 1). Sehingga dapat dikatakan bahwa koridor Jalan Gajah Mada Pontianak merupakan koridor jalan yang strategis sebagai area komersial.

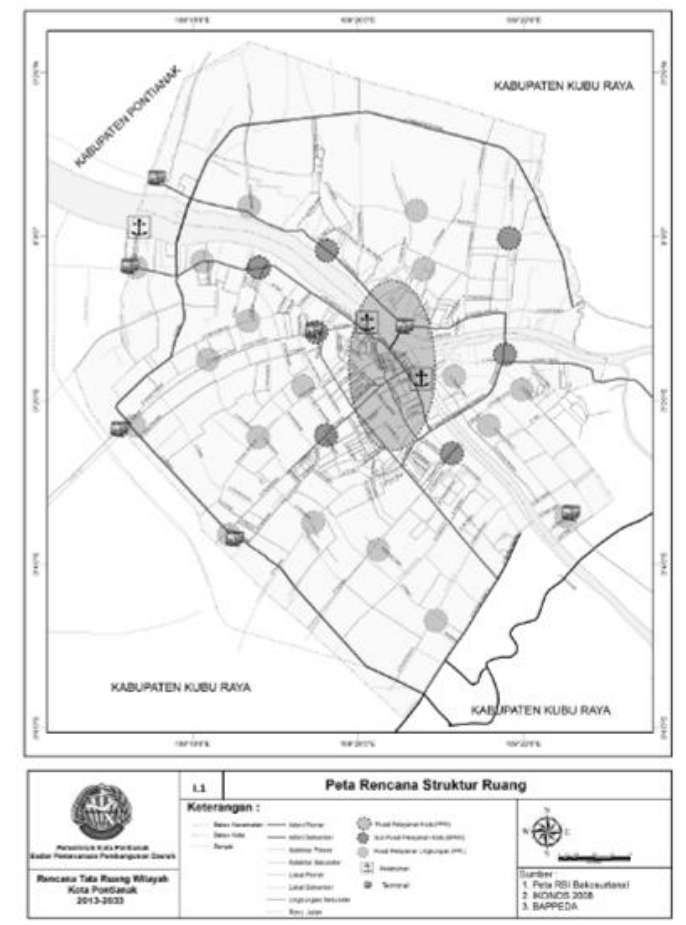

Gambar 1. Peta Rencana Struktur Ruang

Sumber: Rencana Tata Ruang Wilayah Kota Pontianak 2013-2033

Terdapat aktivitas yang memberikan daya tarik tersendiri pada koridor jalan Gajah Mada Pontianak, yaitu aktivitas PKL (Pedagang Kaki Lima) (Lihat Gambar 2). PKL dapat didefinisikan sebagai pedagang yang berjualan di lokasi yang strategis dan pada keramaian, seperti trotoar di depan 
pertokoan/kawasan perdagangan, pasar, sekolah, dan pinggir jalan, dan posisinya cenderung berpindah-pindah (Lida, 2016). Aktivitas PKL ini menjadi satu diantara aktivitas pendukung yang paling banyak dijumpai pada koridor Jalan Gajah Mada Pontianak. Posisi dari PKL ini tersebar di berbagai area dan rata-rata para PKL berjualan di atas pedestrian, area parkir, di area bangunan yang belum buka jam operasionalnya, maupun di area bangunan yang sudah tutup jam operasionalnya. Aktivitas ini berlangsung dari pagi hingga malam hari. Adanya PKL sebagai salah satu bentuk dari aktivitas pendukung turut meramaikan aktivitas perdagangan dan jasa pada koridor.

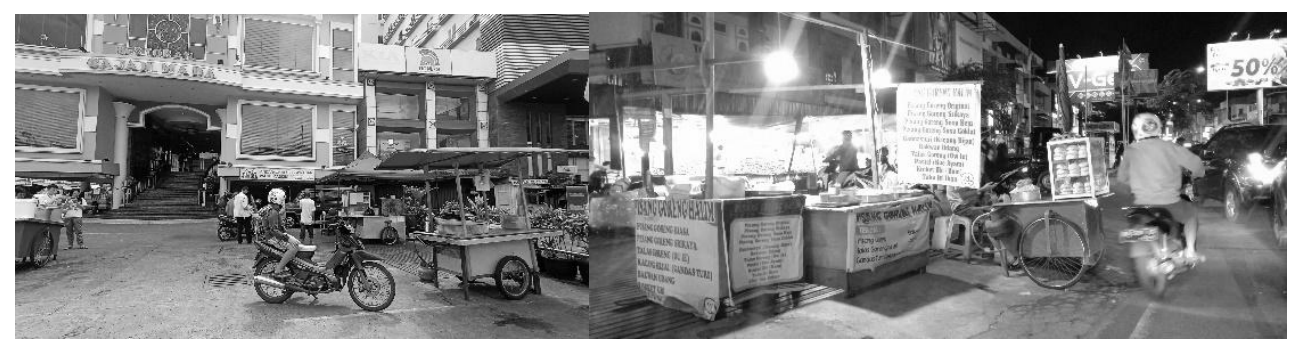

Gambar 2. PKL pada Koridor Jalan Gajah Mada Pontianak

Sumber: Penulis, 2021

Melihat perubahan yang terjadi pada koridor jalan yang dahulunya merupakan daerah pinggiran kota dan sekarang bertransformasi menjadi koridor komersial serta keberadaan aktivitas pendukung berupa PKL dengan jumlah dan posisi yang bervariasi pada setiap ruang di dalam koridor. Hal-hal tersebut dikhawatirkan akan mempengaruhi kualitas visual koridor. Sejalan dengan pendapat (Moughtin, 2003) bahwa aktivitas akan berpengaruh pada vitalitas dan kualitas visual. Metode yang digunakan berupa metode pemetaan perilaku (behaviour mapping) untuk melihat serta memetakan signifikansi keberadaan aktivitas pendukung pada waktu pagi dan malam hari, metode space syntax untuk membantu menilai kualitas visual secara konfigurasi ruang koridor, serta dikombinasikan dengan pengumpulan kuesioner untuk melihat persepsi masyarakat terhadap aktivitas pendukung dan kualitas visual koridor jalan. Kemudian dikorelasikan sehingga menjawab tujuan penelitian yang berupa hubungan antara aktivitas pendukung terhadap kualitas visual koridor Jalan Gajah Mada Pontianak.

\section{Kajian Pustaka}

\section{Definisi Aktivitas Pendukung}

Aktivitas pendukung merupakan satu diantara elemen perancangan kota, dimana fungsi dan kegiatan termasuk di dalamnya (Shirvani, 1985). Fungsi dan kegiatan tersebut akan memperkuat ruang-ruang publik kota karena aktivitas dan ruang fisik saling melengkapi. Semakin dekat dengan pusat kota semakin tinggi intensitas dan beragam kegiatannya (Utomo, 2008). Adanya aktivitas pendukung ini dapat menjadi generator kehidupan di perkotaan. Apabila jalan-jalan di perkotaan tersebut hidup, maka kota tersebut akan menarik dan jika jalan-jalannya tidak memberikan daya tarik maka kota tersebut akan membosankan (Jacobs, 1961). Daya tarik pada jalan kota ini akan mempengaruhi pada penghuni serta pengunjung. Sehingga kota tidak hanya tumbuh dalam bentuk fisik saja, namun juga tumbuh bersamaan dengan masyarakatnya (Spreiregen dalam Sasmito, 2011). Adanya aktivitas-aktivitas ini tetap memperhatikan lokasi yang layak serta strategis sehingga dapat mendukung jalannya aktivitas.

Satu diantara bentuk dari aktivitas pendukung adalah keberadaan PKL. Berdasarkan Peraturan Menteri Dalam Negeri Republik Indonesia Nomor 41 tahun 2012 tentang pedoman penataan dan pemberdayaan pedagang kaki lima menyatakan bahwa Pedagang Kaki Lima, yang selanjutnya disingkat PKL, adalah pelaku usaha yang melakukan usaha perdagangan dengan menggunakan sarana usaha bergerak maupun tidak bergerak, menggunakan prasarana kota, fasilitas sosial, fasilitas umum, lahan dan bangunan milik pemerintah dan/atau swasta yang bersifat sementara/tidak menetap. PKL 
terbagi atas 2 jenis, yaitu PKL tertata dengan izin pemerintah dan PKL binaan yang tidak memiliki izin dari pemerintah serta terletak pada tempat yang dilarang (Wijayaningsih, 2007).

\section{Teknik Pemetaan Perilaku (Behaviour Mapping)}

Pemetaan perilaku (behaviour mapping) digambarkan dalam bentuk sketsa atau diagram mengenai suatu area dimana manusia melakukan berbagai kegiatan (Sommer dalam Fitria, 2018). Metode ini merupakan metode yang objektif untuk mengamati perilaku dan lingkungan binaan yang berkaitan dengan komponen-komponen serta atribut yang ada (Cosco et al., 2010). Tujuan dari metode ini adalah untuk menggambarkan perilaku dalam peta, mengidentifikasikan jenis dan frekuensi perilaku serta menunjukkan kaitan antara perilaku tersebut dengan wujud perancangan dengan spesifik (Pamungkas \& Arsandrie, 2020). Terdapat beberapa jenis teknik dalam pemetaan perilaku (behaviour mapping), yaitu:

\section{Gate Counts}

Gate count dapat memetakan kepadatan arus pergerakan pejalan kaki dalam suatu lokasi yang disajikan secara grafik dan statistik (Andi et al., 2020).

\section{Person Centered Mapping}

Teknik ini menekankan pada pergerakan manusia pada periode waktu tertentu (Fitria, 2018). Teknik ini berhubungan dengan lebih dari satu lokasi. Saat melakukan person centered mapping tahap yang dilakukan adalah mengikuti seorang atau sekelompok orang untuk diamati.

\section{Person Centered Mapping}

Metode ini bertujuan untuk mengetahui bagaimana manusia mengatur dirinya dalam lokasi tertentu (Sommer \& Sommer, 1991). Pada pemetaan ini peneliti ditemukan dengan banyak orang pada satu tempat (Bawembang et al., 2017). Sketsa atau simbol-simbol diperlukan untuk membantu memetakan aktivitas yang terjadi.

\section{Definisi Kualitas Visual}

Kualitas visual dapat dilihat dari petunjuk visual yang diberikan berupa image perception yang dapat dirasakan dengan mata (Ching, 1995). Terdapat beberapa kategori yang digunakan untuk menggambarkan atau menilai suatu bangunan/ lingkungan binaan dari aspek kualitas bentuk satu diantaranya, yaitu kesadaran suatu pergerakan (motion awareness) yang merupakan kesadaran suatu pergerakan (motion awareness) adalah sebuah kualitas dapat dirasakan pengamat melalaui visual dan indera kinestetik (Lynch, 1960). Kualitas ini memperkuat dan mengembangkan apa yang dilakukan pengamat untuk menafsirkan arah atau jarak, dan dapat merasakan sebuah bentuk dalam gerakan itu sendiri. Koridor sebagai ruang pergerakan, memiliki 2 pengaruh langsung pada kualitas lingkungan, yaitu kelangsungan aktivitas komersial dan kualitas visual yang kuat terhadap struktur dan bentuk fisik kota (Halim \& Alimuddin, 2016). Nilai kualitas visual suatu kawasan ditunjukkan oleh adanya kualitas fisik yang terbentuk oleh hubungan atau interelasi antar elemen-elemen visual pada suatu lansekap kota (Smardon et al., 1986).

\section{Space Syntax}

Sistem pada suatu ruang tersusun atas dua faktor utama, yaitu layout dan konfigurasi (Carmona et al., 2003). Kedua faktor penting karena sebagai penentu pergerakan manusia dan dapat dipergunakan dalam pengembangan kawasan. Konfigurasi dipahami sebagai satu hubungan yang ditimbulkan dari adanya kehadiran bersama (co-presence) secara bersamaan dari unsur lain yang saling berhubungan (Hillier, 2007). Dalam konfigurasi ruang kota pada dasarnya mampu menentukan pola, alur dan frekuensi pergerakan manusia (Hillier et al., 1993). Hal ini dapat diidentifikasi dengan memetakan dan memahami posisi jalan terhadap keseluruhan sistem konfigurasi ruang wilayah. Hillier (1996) mengungkapkan bahwa intensitas pergerakan yang tinggi akan mengakibatkan munculnya potential contact. 
Space syntax didefinisikan sebagai metode atau teknik untuk mempresentasikan, memperkirakan, menghitung, atau mengukur sebuah konfigurasi ruang beserta cara menganalisis, dan menafsirkannya (Hillier \& Hanson, 2003). Konsep keterlihatan (visibilitas) mempunyai hubungan yang erat, terkait pergerakan dalam sebuah konfigurasi ruang dan dalam sebuah sistem (Bafna, 2003). Suatu ruang yang terlihat menarik akan mendatangkan orang-orang sehingga sebuah space akan berubah menjadi place karena aktivitas di dalamnya (Yudhanta, 2018). Pergerakan dan interaksi yang terjadi dipengaruhi oleh hadirnya movement generator dan attractor serta setiap akses seperti jalan, secara spontan memiliki potensi menciptakan pergerakan manusia (Hillier, 1999).

Terdapat beberapa jenis mapping, analisis dasar, dan analisis turunan pada space syntax. Untuk mempresentasikan hasil dari analisis space syntax terdapat tiga jenis mapping, yaitu:

1. Axial Map

Axial map dalam skala urban atau kawasan merepresentasikan perpindahan atau movement yang diwakilkan oleh garis yang menyambung ke seluruh ruang dalam suatu sistem.

2. Convex Map

Convex Space adalah ruang yang memenuhi aturan berupa kondisi ketika sebuah garis lurus ditarik dari satu titik ke titik lain dalam sebuah tanpa keluar dari batas ruang tersebut (Hillier \& Hanson, 2003).

\section{Visibility Graph Map}

Visibility graph berkaitan dengan sifat visual tata letak, yaitu inter-visibilitas antara setiap pasangan titik dalam tata letak dan proses hal itu masuk ke dalam konfigurasi visual dari lingkungan binaan. Pendekatan untuk melihat visibilitas dalam konfigurasi dengan metode visibility graph pendekatan ini dirumuskan oleh Turner \& Penn (1999). Visibility graph dalam space syntax juga digunakan untuk menunjukkan visual ruang (visibilitas) dengan hubungan elemen ruang yang mempengaruhi pergerakan dan membantu memahami ruang disekitar kita (Turner et al., 2001).

Untuk melakukan analisis space syntax terdiri dari beberapa jenis, yaitu:

\section{Step Depth}

Jarak topologis atau topological distance sebagai konsep jarak dengan cara menghitung kedalaman (depth) yang diukur dalam langkah (step) (Hillier dalam Siregar, 2014).

\section{Connectivity}

Connectivity merupakan pengukuran dimensi dengan menghitung jumlah ruang yang terhubung langsung dengan ruang lainnya dalam suatu konfigurasi ruang (Hillier et al., 1993). Ruang yang memiliki konektivitas ruang yang baik adalah ruang yang memiliki persinggungan yang paling banyak terhadap ruang lainnya sehingga memiliki derajat hirarki ruang yang lebih utama.

\section{Integration}

Menurut Netzell (2013) nilai integrasi sebagai potensi nilai yang dapat dihitung dari pola pergerakan manusia dan sebagai tingkat kognitif manusia dalam mempersepsikan dan berproses dalam ruang. Semakin banyak ruang yang terhubung dengan ruang pengamatan, semakin tinggi pula nilai integration ruang pengamatan tersebut.

\section{Metode}

Penelitian ini merupakan penelitian dengan pendekatan kuantitatif. Pendekatan kuantitatif merupakan metode penelitian yang digunakan untuk meneliti populasi dan sampel tertentu (Sugiyono, 2018). Pada penelitian ini menggunakan beberapa cara dalam mengumpulkan data, yaitu pemetaan perilaku dengan place centered mapping untuk melihat keberadaan aktivitas pendukung berupa PKL di lapangan, space syntax dengan mapping visibility graph kemudian dianalisis dengan integration untuk melihat kualitas visual berdasarkan konfigurasi ruang koridor, dan didukung dengan pengumpulan kuesioner untuk melihat persepsi masyarakat yang menggunakan koridor Jalan Gajah Mada Pontianak tentang aktivitas pendukung dan kualitas visual. 
Variabel pada aktivitas pendukung berupa jumlah dan posisi dari aktivitas pendukung berbentuk PKL dan kualitas visual dari segi konfigurasi ruang. Pemetaan perilaku (behaviour mapping) menggunakan place centered mapping digunakan sebagai teknik untuk memetakan aktivitas pendukung yang terjadi pada koridor Jalan Gajah Mada Pontianak. Place centered mapping dipilih sebagai pertimbangan bagaimana pengguna memanfaatkan sebuah ruang dan penggunaan teknik ini agar lebih efisien dalam pengumpulan data karena lokasi penelitian yang berupa koridor jalan. Data yang dianalisis dengan space syntax dimodelling ke dalam program depthmapX. Untuk melihat kualitas visual secara konfigurasi ruang digunakan metode space syntax dengan penyajian dalam bentuk visibility graph. Visibility graph membantu memperlihatkan kondisi visual pada sebuah ruang koridor jalan. Data yang dianalisis menggunakan metode space syntax adalah data konfigurasi ruang dengan menggunakan model visibility graph map. Analisis yang digunakan berupa analaisis integration. Analisis ini digunakan untuk melihat nilai integrasi pada konfigurasi ruang koridor sebagai potensi faktor yang menentukan pola pergerakan dan persepsi manusia dalam sebuah ruang. Data-data tersebut kemudian dianalisis dan dikorelasikan sehingga dapat menjawab hubungan aktivitas pendukung terhadap kualitas visual koridor Jalan Gajah Mada Pontianak.

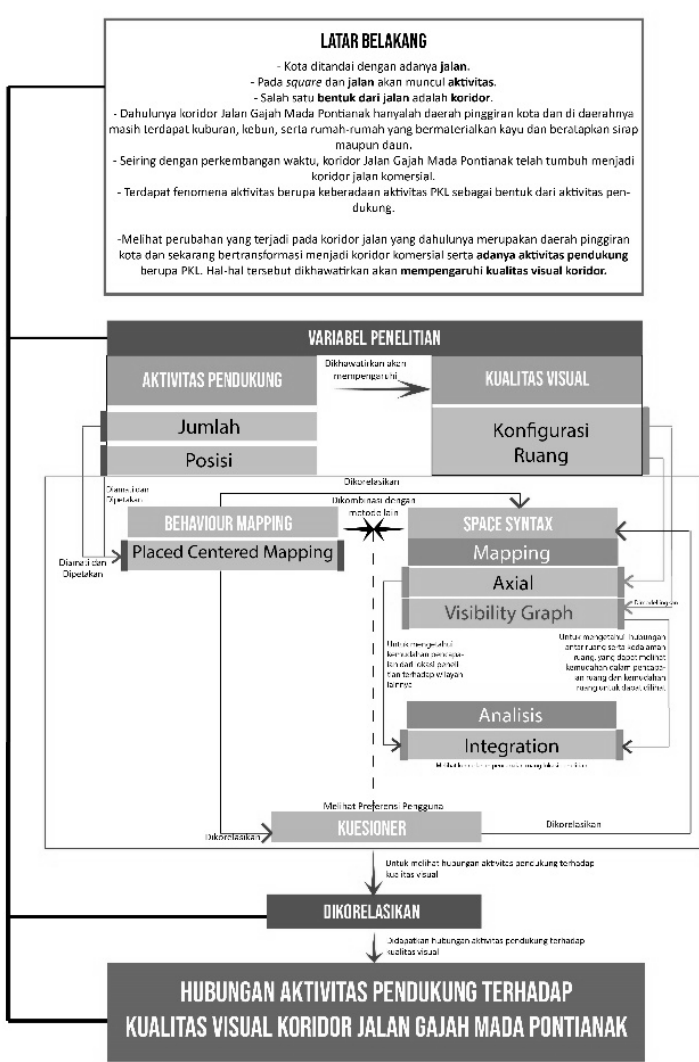

Gambar 3. Skema Metodologi Penelitian Sumber: Penulis, 2021

Area pengamatan dibagi antara jalur kiri dan kanan. Untuk area pengamatan di jalur kanan (Lihat Gambar 4) terdiri dari area pengamatan A1 (wilayah antara J1. K.H. Agus Salim - Jl. Ismail Marzuki) dengan 4 titik pengamatan. Area pengamatan A2 (wilayah antara Jl. Ismail Marzuki - Jl. Dewi Sartika) dengan 19 titik pengamatan, area pengamatan A3 (wilayah antara Jl. Dewi Sartika - Jl. Letjend Suprapto) dengan 13 titik pengamatan, area pengamatan A4 (wilayah antara Jl. Letjend Suprapto Parit Tokaya) dengan 5 titik pengamatan, dan area pengamatan A5 (wilayah antara Parit Tokaya - Jl. Veteran) dengan 6 titik pengamatan. 
Untuk area pengamatan di jalur kiri (Lihat Gambar 4 terdiri dari area pengamatan B1 (wilayah antara Jl. K.H. Agus Salim - Jl. Siam) dengan 11 titik pengamatan, area pengamatan B2 (wilayah antara J1. Siam - Jl. Dr. Setia Budi) dengan 17 titik pengamatan, area pengamatan B3 (wilayah antara Jl. Dr. Setia Budi Jl. Ketapang) dengan 10 titik pengamtan, area pengamatan B4 (wilayah antara Jl. Ketapang - Jl. Hijas), area pengamatan B5 (wilayah antara Jl. Hijas - Parit Tokaya) dengan 16 titik pengamatan, dan area pengamatan B6 dengan 9 titik pengamatan (wilayah antara Parit Tokaya - Jl. Pahlawan). Waktu pengamatan dilakukan pada pagi hari dibatasi dari pukul 06.00 hingga pukul 10.00. Untuk malam hari dibatasi dari pukul 18.00-22.00. Pembatasan waktu ini berdasarkan dimulainya aktivitas seperti waktu buka dan tutup area pertokoan dan ruko, serta keberadaan PKL yang berjualan di pagi dan malam hari.

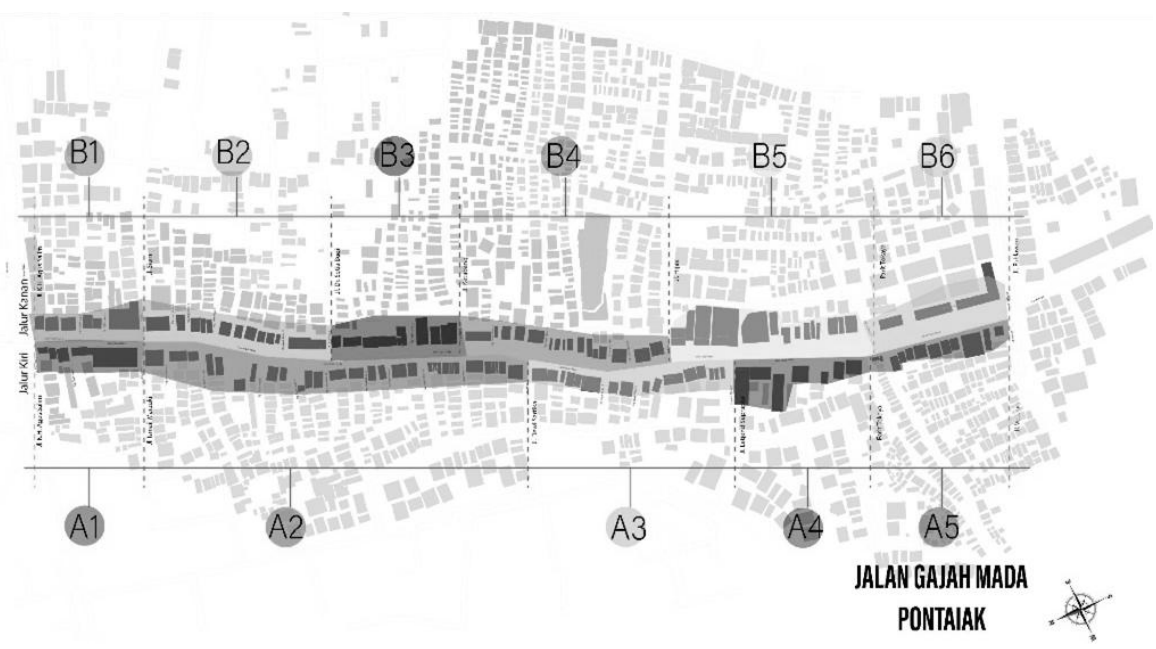

Gambar 4. Area Pengamatan Penelitian

Sumber: Penulis, 2021

\section{Hasil dan Pembahasan}

\section{Hasil Analisis Place Centered Mapping}

Data pemetaan perilaku (behaviour mapping) yang berupa placed centered mapping merupakan data yang tidak real time, karena koridor jalan yang panjang dan hanya menggunakan satu kamera untuk perekaman. Pada saat pengambilan data waktu mulai perekaman pada setiap titik pengamatan berbeda serta pengunjung yang sama dapat dipetakan di lebih dari satu area. Data yang tidak real time bukan menjadi permasalahan karena di setiap area akan diperlakukan berbeda meskipun dengan aktivitas yang sama. Pengambilan data dilakukan pada waktu yang berbeda, yaitu pagi hari (06.0010.00) dan malam hari (18.00-22.00).

Pada setiap area pengamatan memiliki aktivitas serta posisi yang berbeda-beda. Aktivitas pendukung berupa PKL dapat terlihat diberbagai area pengamatan, PKL terbanyak berada pada area terbuka yang luas dan mudah untuk dijangkau kendaraan. Aktivitas PKL lebih banyak dijumpai ketika jam operasional pertokoan belum buka saat pagi hari maupun jam operasional pertokoan telah tutup saat malam hari. Terdapat area pengamatan yang keadaan aktivitasnya tidak signifikan, yaitu pada area pengamatan A5 (wilayah antara Parit Tokaya - Jl. Veteran). Area ini cenderung sepi pengunjung saat pagi dan malam hari. Untuk area B1 perubahan aktivitasnya tidak terlalu signifikan, namun area ini cukup ramai dikunjungi karena fungsi bangunan yang ada berupa rumah makan. 

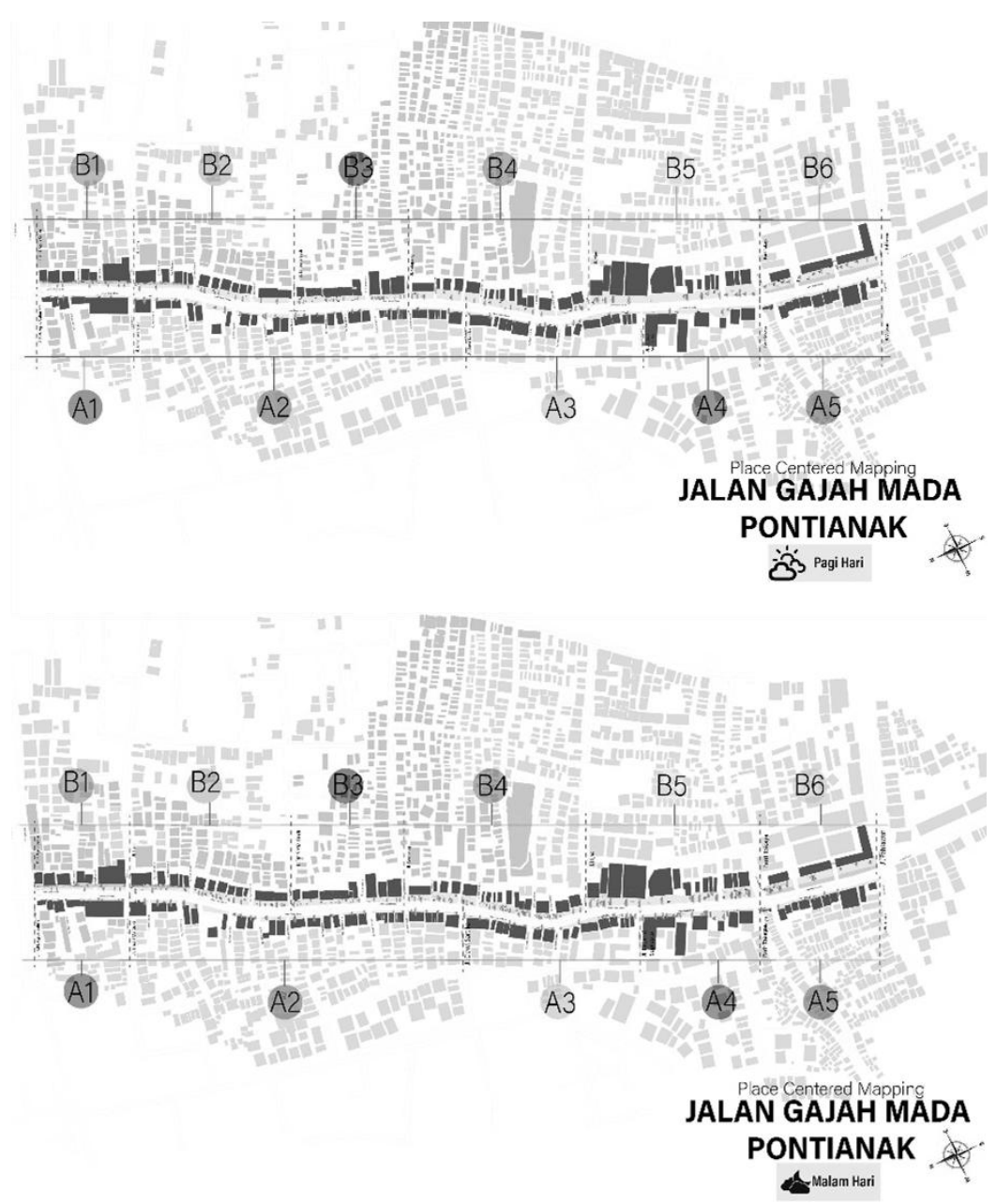

Gambar 5. Hasil Place Centered Mapping Pagi dan Malam Hari Sumber: Penulis, 2021

Perbedaan yang sangat signifikan aktivitas terutama aktivitas PKL yang terjadi saat pagi dan malam hari (Lihat Gambar 5). Saat pagi hari area pengamatan dengan aktivitas yang beragam dapat dilihat pada area pengamatan B3 (wilayah antara J1. Dr. Setia Budi - Jl. Ketapang). Area ini ketika pagi hari didominasi oleh aktivitas PKL yang berjualan di area pertokoan yang jam operasionalnya belum buka. Ketika malam hari, aktivitas PKL tidak banyak ditemukan dikarenakan aktivitas pertokoan yang buka hingga malam hari.

Selain itu, perbedaan yang sangat signifikan antara aktivitas pagi dan malam hari pada koridor Jalan Gajah Mada terjadi pada area pengamatan B2 (wilayah antara J1. Siam - Jl. Dr. Setia Budi) dan B4 (wilayah antara Jl. Ketapang - Jl. Hijas) (Lihat Tabel 1). Saat pagi hari, kondisi aktivitas tidak terlalu ramai. Namun, pada malam hari area ini diramaikan dengan kemunculan aktivitas pendukung, yaitu PKL. Ruang terbuka dengan luasan yang besar pada koridor jalan ini dimanfaatkan para PKL untuk berjualan. Para PKL ini mengatur kursi-kursi plastik di atas pedestrian dan area parkir sehingga memungkinkan untuk mendatangkan pengunjung untuk bersantai di lapak milik masing-masing PKL (Lihat Gambar 5).

Tabel 1. Tabel Nilai Rata-Rata Nilai Integration Visibility Graph pada Space Syntax

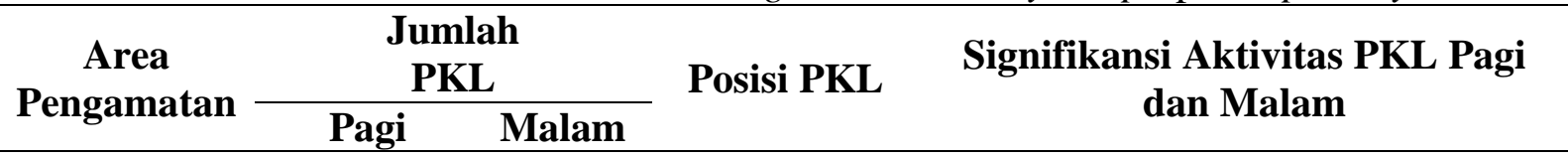




\begin{tabular}{ccccc}
\hline A1 & 0 & 1 & $\begin{array}{c}\text { Di area parkir } \\
\text { pertokoan }\end{array}$ & Tidak Signifikan \\
\hline A2 & 1 & 4 & $\begin{array}{c}\text { Di area parkir } \\
\text { pertokoan }\end{array}$ & Adanya Perubahan yang Signifikan \\
\hline A3 & 1 & 3 & $\begin{array}{c}\text { Di area parkir } \\
\text { pertokoan }\end{array}$ & Adanya Perubahan yang Signifikan \\
\hline A4 & 0 & 2 & $\begin{array}{c}\text { Di area parkir } \\
\text { pertokoan }\end{array}$ & Adanya Perubahan yang Signifikan \\
\hline A5 & 0 & 1 & $\begin{array}{c}\text { Di area parkir } \\
\text { pertokoan }\end{array}$ & Adanya Perubahan yang Signifikan \\
\hline B1 & 1 & 2 & $\begin{array}{c}\text { Di atas } \\
\text { pedestrian }\end{array}$ & Tidak Signifikan \\
\hline B2 & 4 & 10 & $\begin{array}{c}\text { Di atas } \\
\text { pedestrian }\end{array}$ & Adanya Perubahan yang Signifikan \\
\hline B3 & 6 & 2 & $\begin{array}{c}\text { Di area parkir } \\
\text { pertokoan }\end{array}$ & Adanya Perubahan yang Signifikan \\
\hline B4 & 2 & 11 & $\begin{array}{c}\text { Di area parkir } \\
\text { pertokoan }\end{array}$ & Adanya Perubahan yang Signifikan \\
\hline B5 & 4 & 4 & $\begin{array}{c}\text { Di area parkir } \\
\text { pertokoan }\end{array}$ & Tidak Ada Perubahan \\
\hline B6 & 1 & 1 & $\begin{array}{c}\text { Di area parkir } \\
\text { pertokoan }\end{array}$ & Tidak Ada Perubahan \\
\hline
\end{tabular}

Sumber: Penulis, 2021

Posisi dan jumlah PKL bervariasi pada setiap area amatan. Posisi PKL cenderung pada area pedestrian, area parkir pada pertokoan yang jam operasionalnya belum buka maupun sudah tutup. Fungsi bangunan pada koridor yang menarik dapat menjadi magnet mendatangkan pengunjung. Seperti pada area B6 (wilayah antara Parit Tokaya - Jl. Pahlawan) yang merupakan area Pasar Flamboyan kondisinya ramai dikunjungi ketika pagi hari karena fungsinya sebagai pasar tradisional yang menyediakan kebutuhan pokok harian. Hillier (1999) menyatakan bahwa pergerakan dan interaksi dapat dipengaruhi oleh hadirnya movement generator dan attractor. Adanya pergerakan aktivitas pada lahan terbuka yang luas, keberadaan fasilitas, fungsi bangunan yang menarik, kemudahan aksesibilitas, serta adanya PKL sebagai aktivitas pendukung, dapat menjadi daya tarik bagi koridor Jalan Gajah Mada Pontianak.

\section{Hasil Analisis Integration}

Pada penelitian ini untuk menilai kualitas visual koridor Jalan Gajah Mada Pontianak menggunakan space syntax dengan analisis integration. Analisis integration didapatkan dari bantuan perangkat lunak berupa depthmapX. Analisis ini digunakan untuk mengetahui hubungan antar ruang sebagai satu kesatuan sistem. Area yang memiliki nilai integration yang tinggi menandakan keterlihatan (visibilitas) area tersebut mudah untuk dikenali dan mudah untuk dijangkau secara visual sehingga cenderung dikunjungi pengguna dan sebaliknya. Suatu ruang yang terlihat pada penilaian space syntax berkaitan dengan pergerakan dan akan menarik pengunjung untuk datang. 


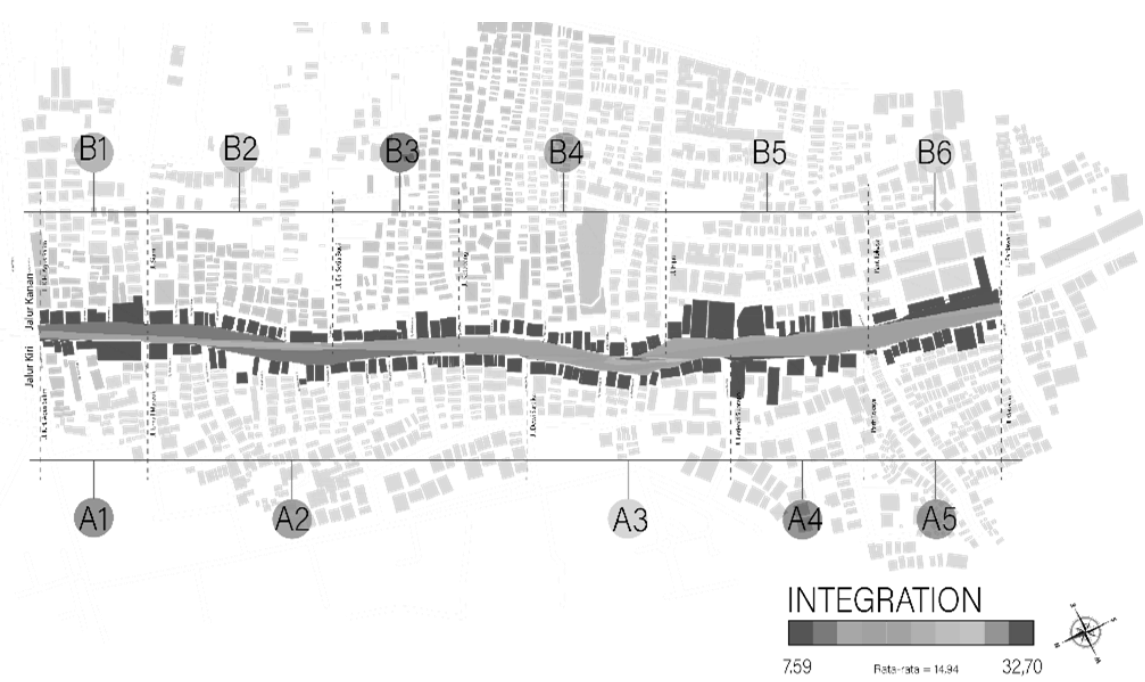

Gambar 6. Hasil Space Syntax dengan Analisis Integration Sumber: Penulis, 2021

Hasil dari analisis integration visibility graph memperlihatkan bahwa di koridor Jalan Gajah Mada Pontianak terdapat area-area dengan keterlihatan (visibilitas) yang mudah dikenali dan dijangkau secara visual maupun sebaliknya. Hal ini dapat dilihat dari nilai rata-rata integration visibility graph yang dihasilkan (Lihat Tabel 1). Kemudahan dan sulitnya pencapaian dapat melihat kecenderungan sebuah ruang untuk dikunjungi pengguna. Apabila dilihat secara keseluruhan antara jalur kanan dan kiri, maka area dengan nilai rata-rata integration tertinggi terletak pada area pengamatan B4 (wilayah antara Jl. Ketapang - Jl, Hijas) dan area dengan nilai terendah terletak pada area pengamatan B1 (wilayah antara Jl. K.H Agus Salim - J1.Siam). Area Pengamatan B4 (wilayah antara Jl. Ketapang - Jl, Hijas) merupakan area yang cenderung dikunjungi pengguna dan Area Pengamatan B1 (wilayah antara J1. K.H Agus Salim - J1.Siam) merupakan area yang kurang dikunjungi pengguna.

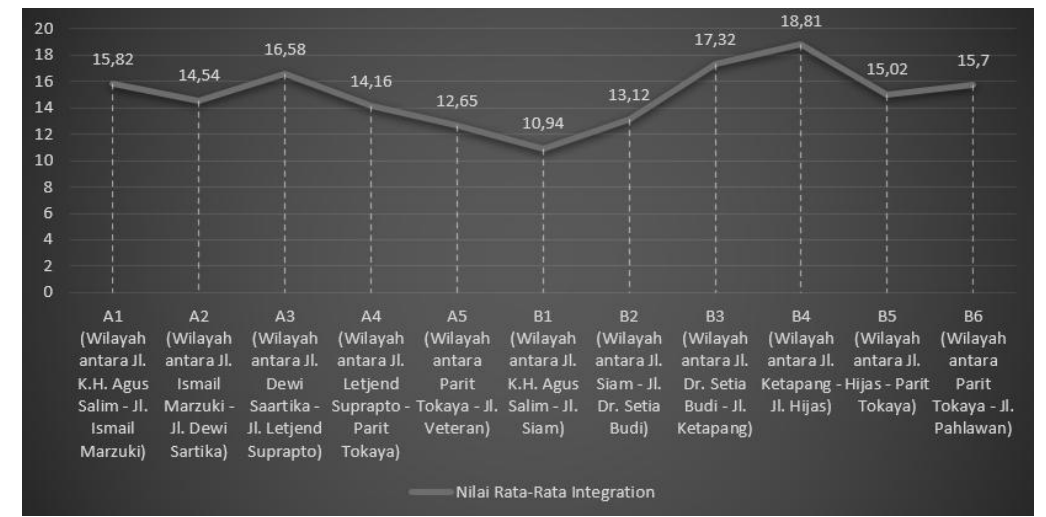

Gambar 4. Hasil Rata-Rata Nilai Integration Visibility Graph

Sumber: Penulis, 2021

\section{Hasil Analisis Kuesioner}

Kuesioner dibagikan menggunakan platform google form. Data yang diperlukan sejumlah 97 sampel. Responden yang mengisi kuesioner ini merupakan responden yang pernah melewati/ mengunjungi/ singgah di koridor Jalan Gajah Mada Pontianak dalam waktu 4 tahun terakhir (20172021). Dalam waktu 4 tahun terakhir ini Jalan Gajah Mada telah banyak melakukan penataan di beberapa area sehingga waktu antara 2017-2021 diambil sebagai syarat responden dalam menjawab pertanyaan yang disajikan. 


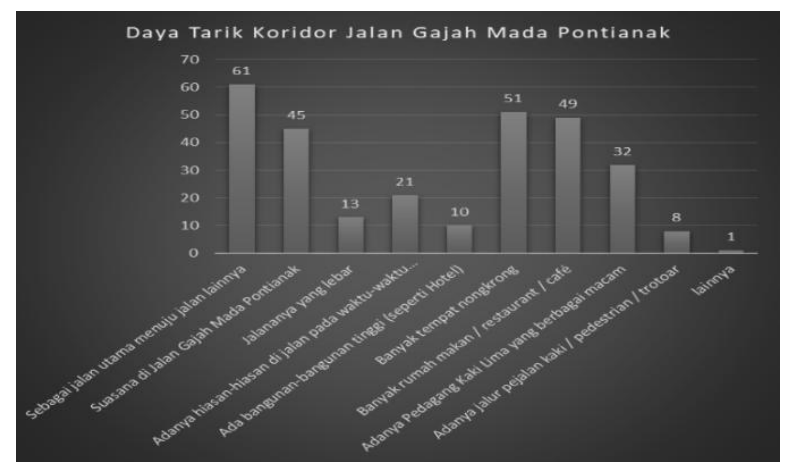

Gambar 5. Daya Tarik Koridor Jalan Gajah Mada Pontianak Sumber: Penulis, 2021

Daya tarik pada koridor Jalan Gajah Mada Pontianak berdasarkan hasil kuesioner adalah sebagai jalan utama yang menuju jalan lainnya (Lihat Gambar 5). Koridor jalan ini merupakan jalan dengan aksesibilitas yang baik karena dapat menuju jalan lainnya dengan melewati gang-gang ataupun jalanjalan yang terkoneksi dengan koridor.

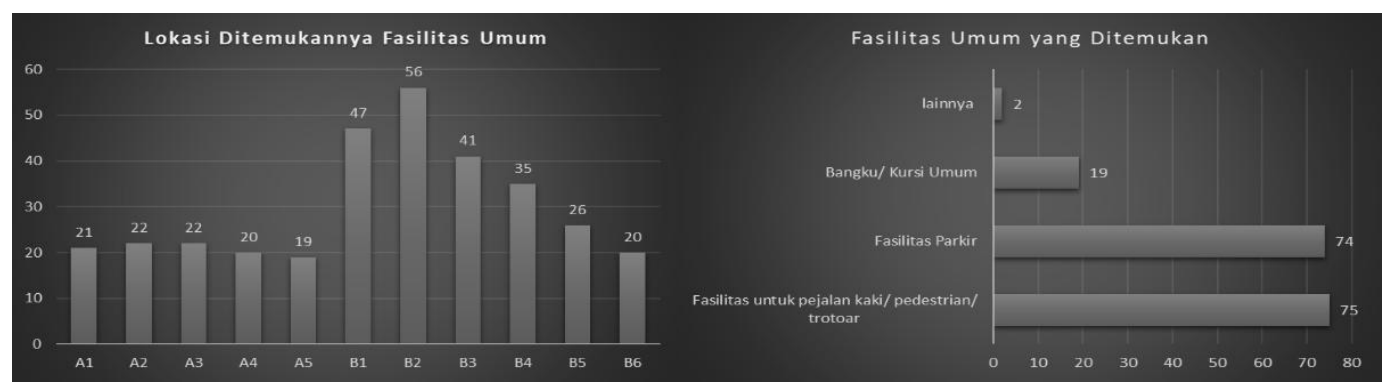

Gambar 6. Preferensi Keberadaan Fasilitas Umum

Sumber: Penulis, 2021

Keberadaan fasilitas umum berupa fasilitas untuk pejalan kaki/ pedestrian/ trotoar dapat menjadi potensi sebuah koridor dapat dikenali (Lihat Gambar 6). Kemudahan fasilitas umum untuk dikenali pada sebuah koridor memberikan kualitas visual tersendiri sehingga orang tertarik untuk berada di koridor. Sehingga dapat meningkatkan pergerakan.

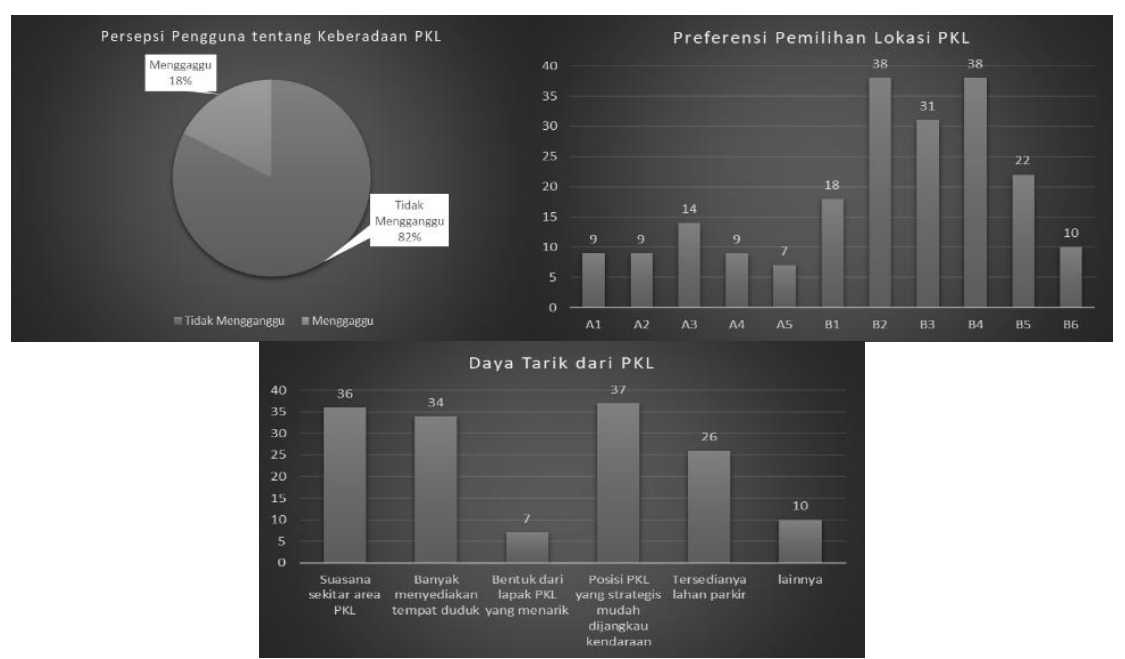

Gambar 7. Preferensi PKL oleh Responden

Sumber: Penulis, 2021 
Adanya PKL sebagai bentuk aktivitas pendukung di koridor Jalan Gajah Mada keberadaanya cenderung tidak mengganggu responden (Lihat Gambar 7). Posisi PKL yang paling banyak dikunjungi responden, yaitu pada area B2 (wilayah antara J1. Siam - J1. Dr. Setia Budi) dan B4 (wilayah antara J1. Ketapang - Jl. Hijas), serta daya tarik dari PKL menurut responden yang paling banyak dipilih ada lokasi keberadaan PKL yang mudah dijangkau.

Berdasarkan kuesioner, persepsi responden terhadap aktivitas pendukung dan kualitas visual koridor Jalan Gajah Mada Pontianak, yaitu keberadaan aktivitas pendukung berupa PKL tidak mengganggu dan mudah untuk dijangkau. Suatu ruang yang mudah dikenali dan mudah untuk diakses dapat menjadi daya tarik pada sebuah koridor untuk dikunjungi. Hal ini dapat mendatangkan pengguna sehingga meningkatkan pergerakan. Faktor lain berupa keberadaan fasilitas umum juga dapat membantu pengguna dalam mengenali sebuah ruang.

\section{Hasil Analisis Korelasi}

Data dikorelasikan menjadi 3 bagian, yaitu antara data placed centered mapping dan space syntax, data placed centered mapping dan kuesioner, dan data kuesioner dan space syntax. Kemudian hasil-hasil korelasi ini dibandingkan sehingga dapat mengetahui hubungan aktivitas pendukung terhadap kualitas visual koridor Jalan Gajah Mada Pontianak. Analisis korelasi ini menggunakan fungsi CORREL pada Microsoft excel untuk melihat korelasi antara jumlah PKL yang dilihat berdasarkan place centered mapping dan nilai rata-rata integration dari space syntax, pemilihan lokasi berdasarkan jumlah PKL berdasarkan place centered mapping dan preferensi pemilihan lokasi oleh responden kuesioner, serta preferensi pemilihan lokasi PKL dari kuesioner dan nilai rata-rata integration dari space syntax, Hasil analisis korelasi tersebut dapat dilihat pada tabel 2.

Tabel 2. Perbandingan Analisis Korelasi Antar Data

\begin{tabular}{ccccc}
\hline Analisis Korelasi & $\begin{array}{c}\text { Waktu } \\
\text { Keberadaan } \\
\text { PKL }\end{array}$ & $\begin{array}{c}\text { Nilai } \\
\text { Korelasi }\end{array}$ & Interpretasi Korelasi & $\begin{array}{c}\text { Tingkat } \\
\text { Kemiripan } \\
\text { Data }\end{array}$ \\
\hline $\begin{array}{c}\text { Antara Place Centered } \\
\text { Mapping dan Space } \\
\text { Syntax }\end{array}$ & Pagi & 0,2712 & Rendah & Cukup Mirip \\
\cline { 2 - 5 } & Malam & 0,2803 & Rendah & Cukup Mirip \\
\hline $\begin{array}{c}\text { Antara Place Centered } \\
\text { Mapping dan } \\
\text { Kuesioner }\end{array}$ & Pagi & 0,759 & Cukup & Sangat Mirip \\
\cline { 2 - 5 } & Malam & 0,813 & Tinggi & Sama Persis \\
\hline $\begin{array}{c}\text { Antara Kuesioner dan } \\
\text { Space Syntax }\end{array}$ & Pagi & 0,327 & Rendah & Cukup Mirip \\
\cline { 2 - 5 }
\end{tabular}

Sumber: Penulis, 2021

Dari hasil analisis korelasi menunjukkan nilai yang positif hal ini menyatakan bahwa adanya hubungan antara aktivitas pendukung dan kualitas visual dengan interpretasi nilai korelasi yang rendah. Semua faktor aktivitas pendukung yang dimasukkan dalam model mempunyai pengaruh terhadap variabel kualitas visual koridor secara bersama-sama dan cukup mirip. Perbedaan hasil ini dipengaruhi persepsi pergerakan menurut space syntax dan persepsi responden kuesioner, serta waktu pengamatan.

Kualitas visual dapat dilihat, dinilai, dan dirasakan oleh mata. Ruang yang tidak ada penghalang menjadi ruang yang memiliki ciri khas sehingga dapat memahami keberadaannya. Aktivitas pendukung merupakan satu diantara elemen perancangan kota yang keberadaanya dapat menjadi movement generator dan attractor pada sebuah koridor. Fakta di lapangan keberadaan aktivitas pendukung berupa PKL turut menyumbang pergerakan yang ada di koridor. Berdasarkan penilaian space syntax dari analisis integration pergerakan yang tinggi pada menandakan kualitas visual pada 
suatu area memiliki nilai yang baik. Untuk melihat pergerakan ini dapat dilihat dengan konfigurasi ruang karena pada dasarnya sebuah konfigurasi ruang kota mampu menentukan pola, alur, dan frekuensi pergerakan manusia. Hal ini akan membentuk kualitas lingkungan yang berpengaruh langsung terhadap kualitas visual.

\section{Kesimpulan}

Seluruh hasil korelasi menyatakan bahwa adanya hubungan yang positif antara aktivitas pendukung terhadap kualitas visual. Jumlah dan posisi dari aktivitas pendukung berupa keberadaan PKL dapat meningkatkan pergerakan pada suatu area. Pergerakan yang tinggi pada space syntax dapat menandakan bahwa kualitas visual pada suatu area memiliki nilai yang baik. Ruang yang mudah untuk dikenali akan menarik pengunjung untuk datang dan aktivitas pendukung berupa PKL dapat menjadi movement generator dan attractor. Selain itu, terdapat faktor lain yang mempengaruhi pergerakan pada suatu area, yaitu aksesibilitas yang mudah, fungsi-fungsi bangunan yang menarik serta keberadaan fasilitas umum. Keberadaan aktivitas pendukung berupa PKL tetap perlu diawasi dan dikontrol keberadaannya serta perlu adanya kerjasama antara pemilik bangunan/ lahan, para PKL, dan pihak pemerintah. Sehingga mewujudkan sebuah koridor perdagangan dan jasa yang bersinergi dalam hal aktivitas dan kualitas visualnya.

\section{Ucapan Terima Kasih}

Ucapan terima kasih disampaikan kepada Ibu Bontor Jumaylinda Br. Gultom, S.T., M.T. selaku dosen pembimbing utama, Bapak Muhammad Nurhamsyah S.T., M.Sc. selaku ketua jurusan sekaligus dosen pembimbing, serta kepada seluruh dosen dan staff Jurusan Arsitektur Universitas Tanjungpura.

\section{Daftar Acuan}

Andi, A., Zain, Z., \& Andi, U. F. (2020). Studi Konfigurasi Ruang Mall (Studi Kasus: Matahari Mall dan Ayani Megamall di Pontianak). Arsitektura, 18(2), 265. https://doi.org/10.20961/arst.v18i2.43471

Bafna, S. (2003). Space syntax: A Brief Introduction to Its Logic and Analytical Techniques. Environment and Behavior, 35(1), 17-29. https://doi.org/10.1177/0013916502238863

Bawembang, E. N., Kumurur, V. A., \& Waani, J. O. (2017). Teritori Dalam Ruang Publik Masyarakat Kampung Cina Di Kota Manado. Jurnal Arsitektur DASENG, 6(1), 32-42

Carmona, M., Heath, T., Oc, T., \& Tiesdell, S. (2003). Public Places - Urban Spaces: The Dimensions of Urban Design. Oxford: Architecture Press

Ching, F. D. K. (1995). A Visual Dictionary of Architecture. New York: Van Nostrand Reinhold

Cosco, N. G., Moore, R. C., \& Islam, M. Z. (2010). Behavior mapping: A method for linking preschool physical activity and outdoor design. Medicine and Science in Sports and Exercise, 42(3), 513-519. https://doi.org/10.1249/MSS.0b013e3181cea27a

Fitria, T. A. (2018). Pengaruh Seting Ruang Terhadap Perilaku Pengguna Dengan Pendekatan Behavioral Mapping. Jurnal Arsitektur Dan Perencanaan (JUARA), 1(2), 183-206. https://doi.org/10.31101/juara.v1i2.775

Halim, H. A., \& Alimuddin, A. A. (2016). Analisa Ruang Publik Koridor Jalan Ratulangi di Makassar. Jurnal Arsitektur, Kota Dan Permukiman (LOSARI), 1(1), 29-33

Hasanah, I. (2014). Pengaruh Activity Support Terhadap Kualitas Visual Koridor Jalan K.H. Agus Salim Semarang. Universitas Diponegoro

Hillier, B. (1996). Cities as Movement Economies. Urban Design International, 1(1), 41-60. https://doi.org/10.1057/udi.1996.5

Hillier, B. (1999). Centrality as a Process: Accounting for Attraction Inequalities in Deformed Grids. 4, 107-127

Hillier, B. (2007). Space is the Machine: A configurational theory of architecture. Cambridge: Cambridge University Press Hillier, B., \& Hanson, J. (2003). The Social Logic of Space. Cambridge: Cambridge University Press

Hillier, B., Penn, A., Hanson, J., Grajewski, T., \& Xu, J. (1993). Natural movement: or, configuration and attraction in urban pedestrian movement. Environment and Planning B: Planning and Design, 20, 26-66. https://doi.org/10.3166/ges.14.73-100

Jacobs, J. (1961). The Death and Life of American Cities. New York: Random House

Jacobs, J. M. (1993). The city unbound: qualitative approaches to the city. Urban Studies, 30(4-5), 827-848. https://doi.org/10.1080/00420989320081931

Jati, D. R., Gultom, B. J. B., Affrilyno, \& Andi. (2021). Kualitas Air dan Udara dari Kota Tepian Air : Analisis Morfologi 
pada Kota Pontianak. 19(1), 170-180. https://doi.org/10.14710/jil.19.1.170-180

Kementerian Dalam Negeri Republik Indonesia. (2012). Peraturan Menteri Dalam Negeri Republik Indonesia Nomor 41 tahun 2012 tentang Pedoman Penataan dan Pemberdayaan Pedagang Kaki Lima. Jakarta: Kementerian Dalam Negeri Republik Indonesia

Krier, R. (1979). Urban Space. London: Rizzoli International Publication Inc

Lida, V. A. O. (2016). Pengaruh Aktivitas Pendukung Terhadap Kenyamanan Pejalan Kaki Di Jl. Zainul Arifin Medan. Universitas Sumatera Utara

Lynch, K. (1960). The Image of the City. Cambridge: MIT Press

Moughtin, C. (2003). Urban Design: Street and Square (Third Edit). Oxford: Architectural Press

Netzell, O. (2013). The Effect of Accessibility on Retail Rents: Testing Integration Value as a Measure of Geographic Location. Journal of Property Research, 30(1), 1-23. https://doi.org/10.1080/09599916.2012.713974

Pamungkas, H., \& Arsandrie, Y. (2020). Behavioral Mapping Dan Adaptasi Terhadap Lingkungan Pada Squatter Settlements (Studi Kasus : Semanggi Rw 23 Surakarta). NALARs, 19(2), 115-130

Sasmito, A. (2011). Pendukung Kegiatan (Activity Support). Dinamika Sains, 9(20), 1-7

Setyowati, M. D. (2017). Pemanfaatan Pedestrian Ways di Koridor Komersial di Koridor Jalan Pemuda Kota Magelang Marcelina. Ruas, 15(1), 13-22

Siregar, J. P. (2014). Metodologi Dasar Space Syntax dalam Analisis Konfigurasi Ruang. Malang: Universitas Brawijaya

Shirvani, H. (1985). The Urban Design Process. New York: Van Nostrand Reinhold Company

Sommer, B., \& Sommer, R. (1991). A practical guide to behavioral research: Tools and techniques (3rd ed.). New York: Oxford University Press

Smardon, R., Palmer, J. E., \& Felleman, J. P. (1986). Foundations for Visual Project Analysis. Canada: John Wiley \& Sons, Inc

Turner, A., Doxa, M., O’Sullivan, D., \& Penn, A. (2001). From Isovists to Visibility Graphs: A Methodology for The Analysis of Architectural Space. Environment and Planning B: Planning and Design, 28, $103-121$. https://doi.org/10.1068/b2684

Turner, A., \& Penn, A. (1999). Making isovists syntactic : isovist integration analysis. 2nd International Symposium on Space Syntax 1999, 1-9

Utomo, A. N. (2008). Pengaruh Persepsi Penghuni dan Aktivitas Pendukung Terhadap Pertumbuhan Koridor ( Studi Kasus : Jl. Gajahmada Semarang). Universitas Diponegoro

Wijayaningsih, R. (2007). Keterkaitan Pedagang Kaki Lima Terhadap Kualitas dan Citra Ruang Publik di Koridor Kartini Semarang Pada Masa Pra-Pembongkaran (Studi Kasus : Penggal Jl.DR.Cipto - Jl.Barito). Universitas Diponegoro

Yudhanta, W. C. (2018). Pengaruh Konfigurasi dan Visibilitas Ruang Pada Aksesibilitas Studi Kasus pada Kawasan XT Square Yogyakarta. Jurnal Arsitektur KOMPOSISI, 12(1), 67. https://doi.org/10.24002/jars.v12i1.1647 